\title{
Analisis Pengaruh Perubahan dan Perputaran Modal Kerja Terhadap Net Profit Margin (NPM) pada PT. Pabrik Kertas Tjiwi Kimia Tbk.
}

\author{
Popon Rabia Adawia ${ }^{1}$, Ayu Azizah ${ }^{2}$ Abdul Rokhim ${ }^{3}$ \\ ${ }^{1}$ Universitas BSI Jakarta \\ popon.pra@bsi.ac.id \\ ${ }^{2}$ Universitas BSI Bandung \\ ayu.azz@bsi.ac.id \\ ${ }^{3}$ STIE YPN Karawang \\ rokhimabdul131@gmail.com
}

\begin{abstract}
(Adawia, Azizah, \& Rokhim, 2019) Adawia, P. R., Azizah, A., \& Rokhim, A. (2019). Analisis Pengaruh Perubahan dan Perputaran Modal Kerja Terhadap Net Profit Margin (NPM) pada PT. Pabrik Kertas Tjiwi Kimia Tbk. Moneter, 6(1), 69-80.
\end{abstract}

\begin{abstract}
This research use 3 variable that is change of working capital and working capital turn as independent variable, Net Profit Margin (NPM) as dependent variable. The purpose of this study is to determine whether or not the influence of changes in working capital and working capital turnover to Net Profit Margin (NPM) at PT. Paper Factory Tjiwi Kimia Tbk. partially or simultaneously. To support the success of this study, collected secondary data in the form of balance sheet and income statement / loss PT. Paper Factory Tjiwi Kimia Tbk. from 2010 to 2016 and company documents relating to the research undertaken. Based on the results of research partially obtained the value of correlation ( $r$ ) of 0.78 (strong) and 0.49 (enough) with t test results obtained value $t$ arithmetic $(t 0)$ is smaller than t table (t0.11,612 and t0.2 $0.799<$ tcount 2.776), while the simultaneous test obtained $r=0.81$ (very strong) with $F$ arithmetic (FO) is also smaller than F table (F0 $3.05<$ Ftabel 6.94). So it can be concluded that the partial or simultaneous changes in working capital and working capital turnover has no positive and significant impact on Net Profit Margin (NPM) at PT. Paper Factory Tjiwi Kimia Tbk.
\end{abstract}

Keywords: Change of working capital, working capital turnover and Net Profi Margin (NPM)

\section{PENDAHULUAN}

Tujuan utama perusahaan mendirikan usahanya adalah mendapatkan laba atau nilai yang optimal dengan memanfaatkan sumber daya yang dimiliki secara efektif dan efisien untuk kelangsungan hidup perusahaan. Dalam usaha pencapaian tujuan tersebut, pihak-pihak yang paling dominan adalah pihak manajemen dan para pemegang saham. Pihak manajemen berkewajiban untuk mempertahankan keberhasilan yang telah dicapai dengan melihat kelemahan dan kekuatan yang terdapat dalam perusahaan serta menjalankan kebijaksanaan perusahaan dengan baik dan tepat. Kebijakan tersebut meliputi bidang pemasaran, produksi, keuangan dan sebagainya.

Untuk tetap melanggengkan usahanya, perusahaan dituntut untuk terus melakukan aktivitas usahanya. Dimana dalam operasinya, perusahaan selalu membutuhkan dana harian misalnya untuk membeli bahan mentah, membayar gaji karyawan, membayar rekening listrik, membayar hutang dan sebagainya. Dana yang digunakan untuk membiayai kegiatan operasi perusahaan sehari-hari disebut modal kerja (working capital) (Harjito, 2014)

Modal kerja yang digunakan diharapkan akan diterima kembali dari hasil penjualan produk yang dihasilkan dalam waktu yang tidak lama. Uang yang diterima dipergunakan lagi untuk kegiatan operasi perusahaan selanjutnya, dan seterusnya dana tersebut berputar selama operasi perusahaan masih beroperasi. Menurut (Kasmir, 2013) mengatakan mengenai modal, Modal kerja yang diartikan sebagai investasi yang ditanamkan pada aktiva lancar atau aktiva jangka pendek, seperti kas, bank, surat-surat berharga, piutang, pesediaan dan aktiva lancar lainnya. Melalui pengelolaan yang baik, dana yang tertanam dalam bentuk modal kerja tersebut dapat dimanfaatkan secara efektif dan seefisien mungkin melalui aktivitas yang dilakukan perusahaan.

Manajemen keuangan berperan penting dalam perencanaan dan pengalokasian modal, karena berhasil tidaknya tujuan perusahaan tergantung pada pengelolaan modal kerja yang tersedia. Pengelolaan modal kerja yang baik dapat diketahui dari berapa 
lama modal kerja itu berputar. Tingkat perputaran modal kerja yang tinggi diimbangi dengan modal kerja yang cukup dengan tingkat penjualan yang tinggi sehingga modal cepat kembali kebentuk semula yakni kas dan piutang. Namun adakalanya perputaran modal kerja yang tinggi bukan berarti efektif akan tetapi sebagai akibat perusahaan kekurangan modal kerja sedangkan tingkat penjualan tinggi. Tingkat perputaran modal kerja yang rendah disebabkan karena banyaknya dana yang tidak dimanfaatkan dalam operasi perusahaan sedangkan tingkat penjualan rendah. Untuk itu, manajemen modal kerja yang efektif dan efisien sangat penting untuk meraih keuntungan (laba) semaksimal mungkin dan untuk menjaga kelangsungan hidup perusahaan dalam jangka panjang (going concern).

Perusahaan pada umumnya sangat memperhatikan masalah laba atau profit, ini adalah alasan utama kenapa perusahaan didirikan. Jumlah laba atau profit yang diperoleh secara teratur serta kecenderungan keuntungan yang terus meningkat merupakan faktor yang sangat penting dalam menilai profitabilitas perusahaan. Bagi pimpinan, profitabilitas digunakan sebagai tolak ukur untuk mengetahui berhasil atau tidaknya perusahaan yang dipimpinnya. Bagi penanam modal, profitabilitas digunakan sebagai tolak ukur prospek modal yang ditanamkan dalam perusahaan. Menurut Sutrisno, profitabilitas adalah kemampuan perusahaan dalam menghasilkan keuntungan dengan semua modal yang bekerja didalamnya (Adawia, 2017) Berdasarkan pendapat diatas dapat disimpulkan bahwa profitabilitas adalah mengukur efektifitas manajemen berdasarkan hasil pengembalian yang dihasilkan dari volume penjualan, total aktiva, dan modal sendiri.

Profitabilitas dapat diukur dengan Net Profit Margin $(N P M)$ atau Marjin Laba Bersih. Menurut Hery (Hery, 2015) Net Profit Margin merupakan keuntungan penjualan setelah menghitung seluruh biaya dan pajak penghasilan. Margin ini menunjukkan perbandingan laba bersih setelah pajak (net income) dengan penjualan bersih (net sales). Semakin tinggi margin laba bersih berarti semakin tinggi pula laba bersih yang dihasilkan dari penjualan bersih. Sebaliknya, semakin rendah margin laba bersih berarti semakin rendah pula laba bersih yang dihasilkan dari penjualan bersih.

Dalam era globalisasi ini yang diikuti dengan perkembangan teknologi yang begitu cepat, dunia usaha semakin tumbuh dan berkembang pesat. Hal ini mengakibatkan persaingan antar perusahaan semakin ketat. Perusahaan yang kuat akan bertahan sedangkan yang tidak mampu bersaing akan mengalami kebangkrutan dan collaps. Perkembangan tersebut dapat kita cermati salah satunya dari sektor industri pulp dan kertas. Perkembangan teknologi informasi yang begitu cepat mengikis keberadaan industri ini, dimana sekarang ini media cetak telah mampu dikonversi ke dalam dunia digital.
Perkembangan teknologi berdampak pada perilaku masyarakat. Masyarakat membutuhkan informasi dan komunikasi yang serba cepat, dari awalnya hanya dengan membaca text, kini kita bisa mendengar, menonton bahkan berinteraksi langsung dengan pembuat berita (content provider-nya). Ini akan memberi dampak bagi pelaku bisnis media cetak kemudian merembet pada industri pulp dan kertas.

Berdasarkan uraian di atas, penulis melakukan penelitian yang berhubungan dengan modal kerja dan perputarannya terhadap tingkat pencapaian profitabilitas, dalam hal ini adalah Net Profit Margin yang diperoleh perusahaan pulp dan kertas dari tahun ke tahun.

\section{METODOLOGI PENELITIAN}

Populasi yang digunakan dalam penelitian ini adalah data laporan keuangan tahunan PT. Pabrik Kertas Tjiwi Kimia Tbk. yang tercatat dalam Bursa Efek Indonesia (BEI). Sedangkan sampel yang digunakan adalah data laporan keuangan dari tahun 2010 sampai dengan tahun 2016 (data yang ditemukan dalam BEI), maka teknik pengambilan jumlah sampel menggunakan sampling jenuh. Sampling jenuh adalah teknik penentuan sampel bila semua anggota populasi digunakan sebagai sampel (Sugiyono, 2012)

Penelitian ini merupakan jenis penelitian asosiatif kuantitatif. Artinya, penelitian ini mengolah dan menganalisis data yang bersifat kuantitatif/statistic yang diperoleh dari laporan keuangan perusahaan tentang komponen penyusun variabel perubahan modal kerja, perputaran modal kerja, dan Net Profit Margin kemudian menghubungkan tiap variabel tersebut untuk diketahui ada atau tidak pengaruh dan hubungannya. Variabel independen yang digunakan dalam penelitian ini adalah perubahan modal kerja (X1) dan perputaran modal kerja (X2), sedangkan variabel dependen yang digunakan adalah Net Profit $\operatorname{Margin}(\mathrm{Y})$.

Untuk memudahkan pengukuran dari variabelvariabel yang telah ditetapkan, berikut ini disajikan pengukurannya dalam bentuk tabel:

Tabel 1 Operasionalisasi Variabel

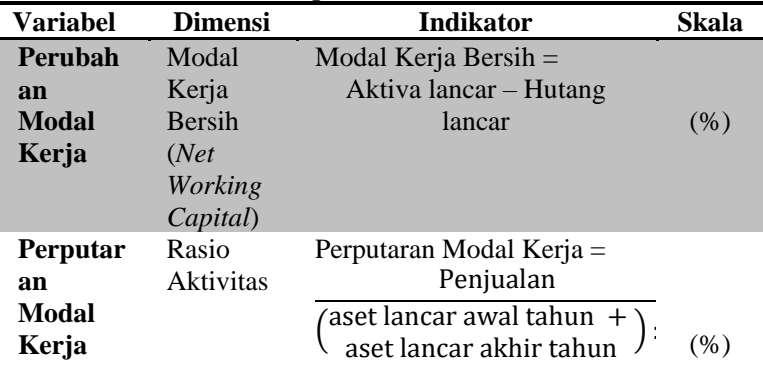

\begin{tabular}{llc}
$\begin{array}{l}\text { Net } \\
\text { Profit }\end{array}$ & Rasio & Marjin Laba Bersih $=$ \\
Margin & itas & Laba bersih \\
(NPM) & & Penjualan bersih \\
& & \\
\hline Sum & & \\
\end{tabular}

Sumber : (Harjito, 2014)(Hery, 2015) 


\section{Uji Statistik}

a. Analisis Regresi Linier Berganda

Regresi linier berganda merupakan prosedur yang berfungsi untuk melihat hubungan linier antara lebih dari satu variabel yang diidentifikasi sebagai variabel independen atau bebas dengan satu variabel lain yang diidentifikasi sebagai variabel dependen atau tergantung (Jonathan dan Hendra Nur Salim, 2017).

Berikut ini persamaan umum regresi linier berganda:

$\mathbf{Y}=\mathbf{a}+\mathbf{b}_{1} \mathbf{X}_{1}+\mathbf{b}_{2} \mathbf{X}_{2}+\ldots+\mathbf{b}_{\mathbf{k}} \mathbf{X}_{\mathbf{k}}+\mathbf{e}$

(Jonathan dan Hendra Nur Salim, 2017).

Artinya:

Y : Variabel tergantung atau dependen atau disebut juga variable kriteria, yaitu variabel yang nilainya akan diprediksi.

a : Titik potong garis regresi pada sumbu vertikal (Y) atau disebut intersep atau konstanta, yaitu nilai $\mathrm{Y}$ yang diprediksikan bila nilai $\mathrm{X}=0$.

b : Tingkat kemiringan garis regresi atau koefisien regresi, yaitu besarnya perubahan nilai $\mathrm{Y}$ bila nilai $\mathrm{X}$ berubah sebesar satu satuan.

X : Variabel bebas atau independen atau disebut juga sebagai prediktor, yaitu variabel yang digunakan untuk memprediksi nilai Y.

e : Epsilon atau error pada garis regresi, merupakan selisih nilai Y yang diprediksikan dengan nilai $\mathrm{Y}$ yang diperoleh atau disebut juga sebagai residual $\left(\mathrm{Y}-\mathrm{Y}_{0}\right)$.

k : Banyaknya semua variabel

Karena dalam penelitian ini menggunakan tiga variabel, yakni dua variabel independen/bebas dan satu variabel dependen/terikat maka persamaan regresi seperti di bawah ini:

$\mathbf{Y}=\mathbf{a}+\mathbf{b}_{1} \mathbf{X}_{1}+\mathbf{b}_{2} \mathbf{X}_{2}$

Dari persamaan di atas kita harus mencari nilai $b_{1}$ dan $b_{2}$ dan a dengan menggunakan rumus statistik sebagai berikut:

$$
\begin{aligned}
& \left(\mathrm{SS}_{2}\right)\left(\mathrm{SCP}_{1 \mathrm{y}}\right)-\left(\mathrm{SCP}_{12}\right)\left(\mathrm{SCP}_{2 \mathrm{y}}\right) \\
& \mathbf{b}_{1}=\quad r_{12 . y}=\frac{r_{12}-r_{1 y} r_{2 y}}{\square\left(1-r_{1 y}^{2}\right)\left(1-r_{2 y}^{2}\right)} \\
& \left(\mathrm{SS}_{1}\right)\left(\mathrm{SS}_{2}\right)-\left(\mathrm{SCP}_{12}\right)^{2} \\
& \mathbf{b}_{2}=\frac{\left(\mathrm{SS}_{1}\right)\left(\mathrm{SCP}_{2 \mathrm{y}}\right)-\left(\mathrm{SCP}_{12}\right)\left(\mathrm{SCP}_{1 \mathrm{y}}\right)}{\left(\mathrm{SS}_{1}\right)\left(\mathrm{SS}_{2}\right)-\left(\mathrm{SCP}_{12}\right)^{2}} \\
& \mathbf{a}=\mathbf{Y}-\mathbf{b}_{1} \mathbf{X}_{1}-\mathbf{b}_{2} \mathbf{X}_{2}=\left(\frac{\sum \mathrm{Y}}{\mathrm{n}}\right)-\mathbf{b} 1\left(\frac{\sum \mathrm{X} 1}{\mathrm{n}}\right)-\mathbf{b} \mathbf{2}\left(\frac{\sum \mathrm{X} 2}{\mathrm{n}}\right)
\end{aligned}
$$

Dengan:

$$
\begin{aligned}
& \mathrm{SS}_{1}=\sum \mathrm{x}_{1}{ }^{2}=\sum \mathrm{X}_{1}{ }^{2}-\frac{\left(\sum \mathrm{X}_{1}\right)^{2}}{\mathrm{n}} \\
& \mathrm{SS}_{2}=\sum \mathrm{x}_{2}^{2}=\sum \mathrm{X}_{2}{ }^{2}-\frac{\left(\sum \mathrm{X}_{2}\right)^{2}}{\mathrm{n}} \\
& \mathrm{SS}_{\mathrm{y}}=\sum \mathrm{y}^{2}=\sum \mathrm{Y}^{2}-\frac{\left(\sum \mathrm{Y}\right)^{2}}{\mathrm{n}} \\
& \mathrm{SCP}_{12}=\sum \mathrm{x}_{1} \mathrm{X}_{2}=\sum \mathrm{X}_{1} \mathrm{X}_{2}-\frac{\left(\sum \mathrm{X}_{1}\right)\left(\sum \mathrm{X}_{2}\right)}{\mathrm{n}} \\
& \mathrm{SCP}_{1 \mathrm{y}}=\sum \mathrm{x}_{1 \mathrm{y}}=\quad \sum \mathrm{X}_{1} \mathrm{Y}-\frac{\left(\sum \mathrm{X}_{1}\right)\left(\sum \mathrm{Y}\right)}{\mathrm{n}} \\
& \mathrm{SCP}_{2 \mathrm{y}}=\sum \mathrm{x}_{2} \mathrm{y}=\quad \sum \mathrm{X}_{2} \mathrm{Y}-\frac{\left(\sum \mathrm{X}_{2}\right)\left(\sum \mathrm{Y}\right)}{}
\end{aligned}
$$

(Jonathan dan Hendra Nur Salim, 2017)

Keterangan:

$\mathrm{SS}_{1} \quad$ : Jumlah kuadrat deviasi $\mathrm{x}_{1}$ (Sum Square)

$\mathrm{SS}_{2}$ : Jumlah kuadrat deviasi $\mathrm{x}_{2}$ (Sum Square)

$\mathrm{SS}_{\mathrm{y}}$ : Jumlah kuadrat deviasi y (Sum Square)

$\mathrm{SCP}_{12}$ : Jumlah perkalian silang antara deviasi $\mathrm{x}_{1}$ dan deviasi $\mathrm{x}_{2} \quad$ (SCP,Sum Cross Product)

$\mathrm{SCP}_{1 \mathrm{y}}$ : Jumlah perkalian silang antara deviasi $\mathrm{x}_{1}$ dan deviasi $\mathrm{y}$

$\mathrm{SCP}_{2 \mathrm{y}}$ : Jumlah perkalian silang antara deviasi $\mathrm{x}_{1}$ dan deviasi $\mathrm{y}$

b. Koefisien Korelasi Parsial

Koefisien korelasi adalah indeks atau bilangan yang digunakan untuk mengukur derajat hubungan yang meliputi kekuatan hubungan dan bentuk atau arah hubungan.

Untuk mengetahui seberapa kuat hubungan antar variabel secara sendiri-sendiri/parsial (Jonathan dan Hendra Nur Salim, 2017) digunakan rumus statistik sebagai berikut:

1) Menghitungkoefisien korelasi variabel $Y$ dan $\mathrm{X}_{1}\left(\mathrm{X}_{2}\right.$ dianggap konstan) digunakan rumus :

$$
r_{1 y .2}=\frac{r_{1 y}-r_{2 y} r_{12}}{\square\left(1-r_{2 y}^{2}\right)\left(1-r_{12}^{2}\right)}
$$

2) Menghitungkoefisien korelasi variabel $Y$ dan $\mathrm{X}_{2}\left(\mathrm{X}_{1}\right.$ dianggap konstan) digunakan rumus :

$$
r_{2 y .1}=\frac{r_{2 y}-r_{1 y} r_{12}}{\square\left(1-r^{2}{ }_{1 y}\right)\left(1-r_{12}^{2}\right)}
$$

3) Menghitungkoefisien korelasi variabel $X_{1}$ dan $\mathrm{X}_{2}$ (Y dianggap konstan) digunakan rumus : 


$$
\begin{aligned}
& r_{1 y}=\frac{\mathrm{SCP}_{1 \mathrm{y}}}{\square\left(\mathrm{SS}_{1}\right)\left(\mathrm{SS}_{\mathrm{y}}\right)} \\
& \mathrm{r}_{2 \mathrm{y}}= \frac{\mathrm{SCP}_{2 \mathrm{y}}}{\square\left(\mathrm{SS}_{2}\right)\left(\mathrm{SS}_{\mathrm{y}}\right)} \\
& \mathrm{r}_{12}=\frac{\mathrm{SCP}_{12}}{\square\left(\mathrm{SS}_{1}\right)\left(\mathrm{SS}_{2}\right)}
\end{aligned}
$$

Keterangan:

$\mathrm{r}_{1 \mathrm{y}=} \mathrm{r}_{\mathrm{x} 1 \mathrm{y}}=$ koefisien korelasi antara $\mathrm{X}_{1}$ dan $\mathrm{Y}$

$r_{2 y}=r_{x 2 y}=$ koefisien korelasi antara $X_{2}$ dan $Y$

$r_{12}=r_{x 1 \times 2}=$ koefisien korelasi antara $X_{1}$ dan $X_{2}$

Untuk mengetahui hubungan antar variabel digunakan interval koefisien korelasi (r):

$\mathrm{r}=-1 \leq \mathrm{r} \leq 1$

jika :

$r=-1$, artinya hubungan antara $X$ dan $Y$ sempurna dan mempunyai hubungan linier negatif.

$\mathrm{r}=0$, artinya tidak ada hubungan antara $\mathrm{X}$ dan $\mathrm{Y}$.

$\mathrm{r}=1$, artinya hubungan antara $\mathrm{X}$ dan $\mathrm{Y}$ sempurna dan mempunyai hubungan linier positif (Jonathan dan Hendra Nur Salim, 2017)

Kemudian tingkat hubungan koefisien korelasi dapat diketahui dengan menggunakan tabel pedoman interpretasi korelasi sebagai berikut:

Tabel 2 Tingkat Hubungan Koefisien Korelasi

\begin{tabular}{ll}
\hline Interval Koefisien & Tingkat Hubungan \\
\hline $0.00-0.199$ & Sangat Rendah \\
$0.20-0.399$ & Rendah \\
$0.40-0.599$ & Cukup \\
$0.60-0.799$ & Kuat \\
$0.80-1.000$ & Sangat Kuat \\
\hline
\end{tabular}

Sumber : (Sugiyono, 2012)

c. Koefisien Korelasi Simultan

Koefisien korelasi simultan digunakan untuk mengetahui seberapa kuat hubungan variabel independen secara bersama-sama/simultan terhadap variabel dependen. Untuk mengetahui hubungannya digunakan rumus statistik di bawah ini:

$\mathbf{R}_{\mathbf{y} 12}=\quad \sqrt{\frac{\mathrm{r}^{2}{ }_{1 y}+\mathrm{r}^{2}{ }_{2 y}-2 \mathrm{r}_{1 y} \mathrm{r}_{2 \mathrm{y}} \mathrm{r}_{12}}{1-\mathrm{r}_{12}}}$

(Jonathan dan Hendra Nur Salim, 2017)

d. Koefisien Determinasi (KD)

Koefisisen determinasi digunakan untuk menyatakan besarnya proporsi variasi dari variabel dependen (tergantung) yang dapat dijelaskan oleh proporsi variabel independen (bebas) atau predictor (Jonathan dan Hendra Nur Salim, 2017). Untuk menghitung besarnya koefisien determinasi berganda Rumusnya:

$\mathrm{KDB}=\mathbf{R}_{\mathrm{y} 12}^{2} \times 100 \%$

2. Uji t (Pengujian Kelayakan Hipotesis Parsial) Menurut Danang, pengujian hipotesis statistic adalah prosedur yang memungkinkan keputusan dibuat, yaitu keputusan untuk menolak atau menerima hipotesis, digunakan data yang sedang dipersoalkan/diujikan (Azizah, 2017).

Pengujian hipotesis dengan menggunakan uji $\mathrm{t}(\mathrm{t}$ test $)$ bertujuan untuk mengetahui apakah variabel independen/bebas dalam model regresi berpengaruh terhadap variabel dependen/terikat.

Langkah pertama yang dilakukan dalam melakukan pengujian secara parsial menurut (Jonathan dan Hendra Nur Salim, 2017) adalah merumuskan hipotesis penelitian yaitu:

$\mathrm{HO}_{1}: \beta_{1}=0\left(\right.$ Variabel $\mathrm{X}_{1}$ tidak berpengaruh terhadap $\mathrm{Y}$ secara signifikan)

$\mathrm{H} 1_{1}: \beta_{1} \neq 0$ (Variabel $\mathrm{X}_{1}$ berpengaruh terhadap $\mathrm{Y}$ secara signifikan).

$\mathrm{HO}_{2}: \beta_{2}=0$ (Variabel $\mathrm{X}_{2}$ tidak berpengaruh terhadap $\mathrm{Y}$ secarasignifikan).

$\mathrm{H}_{2}: \beta_{2} \neq 0$ (Variabel $\mathrm{X}_{2}$ berpengaruh terhadap $\mathrm{Y}$ secara signifikan).

Karena dalam penelitian ini menggunakan tingkat kepercayaan sebesar $95 \%$ maka nilai probabilitas $/ \mathrm{alpa} / \alpha=5 \%$ atau 0,05 .

Menghitung nilai t tabel dengan ketentuan sebagai berikut:

Nilai $\alpha=5 \%$ atau 0,05 harus dibagi dua sehingga menjadi 0,025 .

Degree of Freedom $(\mathrm{DF})=\mathrm{n}-\mathrm{k}$ (jumlah data dikurangi jumlah variabel).

Langkah selanjutnya adalah mencari nilai $\mathrm{t}$ hitung dengan menggunakan rumus:

thitung $\left(\mathrm{t}_{0}\right)=\frac{\mathrm{b}_{\mathrm{k}}}{\mathrm{s} \mathrm{b}_{\mathrm{k}}}$

Dengan:

$$
\begin{aligned}
& \mathrm{Sb}_{1}=\quad \mathrm{Sy}_{1.2}=\quad \sqrt{\frac{\mathrm{MS}_{\mathrm{res}}}{\mathrm{SS}_{1}\left(1-\mathrm{r}_{12}{ }^{2}\right)}} \& \mathrm{r}_{12}{ }^{2}=\frac{\left(\mathrm{SCP}_{12}\right)^{2}}{\left(\mathrm{SS}_{1}\right)\left(\mathrm{SS}_{2}\right)} \\
& \mathrm{Sb}_{2}=\frac{\mathrm{SS}_{\mathrm{res}}}{\mathrm{SS}_{\mathrm{y}}}=\sqrt{\mathrm{Sy}_{2.1}=} \frac{\mathrm{MS}_{\mathrm{res}}}{\mathrm{SS}_{2}\left(1-\mathrm{r}_{12}{ }^{2}\right)}
\end{aligned}
$$


MSres diketahui dengan menggunakan rumus:

$$
\text { MSres }=\frac{\mathrm{SSy}-\left\{\mathrm{b}_{1}\left(\mathrm{SCP}_{1 \mathrm{y}}\right)+\mathrm{b}_{2}\left(\mathrm{SCP}_{2 \mathrm{y}}\right)\right\}}{\mathrm{k}-1}
$$

(Jonathan dan Hendra Nur Salim, 2017)

Keterangan:

$\mathrm{Sb}_{1}=$ kesalahan baku dari intersep $\mathrm{b}_{1}$

$\mathrm{Sb}_{2}=$ kesalahan baku dari intersep $\mathrm{b}_{2}$

$\mathrm{Sy}_{1.2}=$ kesalahan baku dari koefisien regresi linier berganda $b_{1}$

$\mathrm{Sy}_{2.1}=$ kesalahan baku dari koefisien regresi linier berganda $b_{2}$

MSres = rata-rata kuadrat residu (MS/Mean Square)

Setelah $\mathrm{t}$ hitung ditemukan kemudian membandingkannya dengan $\mathrm{t}$ tabel untuk ditarik kesimpulannya dengan kriteria sebagai berikut:

Jika $\mathrm{t}$ hitung $\left(\mathrm{t}_{0}\right)>\mathrm{t}$ tabel maka $\mathrm{H} 0$ ditolak dan $\mathrm{H} 1$ diterima.

Jika t hitung $\left(\mathrm{t}_{0}\right)<\mathrm{t}$ tabel maka H0 diterima dan H1 ditolak.

\section{HASIL DAN PEMBAHASAN}

\section{Modal Kerja}

Modal kerja dalam penelitian ini menggunakan konsep kualitatif yakni modal kerja bersih (net working capital). Modal kerja bersih di dapat dari hasil pengurangan antara aktiva lancar dikurangi dengan hutang lancar. Setelah diketahui modal bersih pertahun, kemudian dianalisis perubahannya (naik/turun) dengan cara membandingkannya dengan modal bersih tahun sebelumnya. Data jumlah modal bersih tersebut diambil dari neraca laporan keuangan PT. Pabrik Kertas Tjiwi Kimia Tbk. tahun 2009 sampai dengan tahun 2016 berikut ini:

Tabel 3. Jumlah Modal Kerja PT. Pabrik Kertas Tjiwi Kimia Tbk tahun 2009 s/d Tahun 2016 (dalam dolar AS)

\begin{tabular}{cccc}
\hline THN & $\begin{array}{c}\text { AKTIVA } \\
\text { LANCAR }\end{array}$ & $\begin{array}{l}\text { HUTANG } \\
\text { LANCAR }\end{array}$ & $\begin{array}{c}\text { MODAL } \\
\text { KERJA }\end{array}$ \\
\hline 2009 & 920.801 .000 & 389.011 .000 & 531.790 .000 \\
2010 & 917.699 .000 & 418.397 .000 & 499.302 .000 \\
2011 & 1.150 .989 .000 & 598.290 .000 & 552.699 .000 \\
2012 & 1.262 .551 .000 & 524.443 .000 & 738.108 .000 \\
2013 & 1.198 .904 .000 & 540.105 .000 & 658.799 .000 \\
2014 & 1.067 .583 .000 & 561.851 .000 & 505.732 .000 \\
2015 & 829.331 .000 & 579.075 .000 & 250.256 .000 \\
2016 & 598.774 .000 & 429.383 .000 & 169.391 .000 \\
TOTAL & 7.946 .632 .000 & 4.040 .555 .00 & 3.906 .077 .00 \\
& & 0 & 0 \\
\hline $\begin{array}{l}\text { RATA- } \\
\text { RATA }\end{array}$ & 993.329 .000 & 505.069 .375 & 488.259 .625 \\
\hline
\end{tabular}

Sumber : Laporan Keuangan Neraca PT. Tjiwi Kimia 2009 s/d 2016
Tabel 4. Perubahan Modal kerja PT. Pabrik Kertas Tjiwi Kimia Tbk tahun 2009 s/d tahun 2016 (dalam dolar AS)

\begin{tabular}{|c|c|c|c|c|c|}
\hline \multirow[t]{2}{*}{ THN } & AKTIVA & HUTANG & MODAL & PERU- & $(\%)$ \\
\hline & LANCAR & LANCAR & KERJA & BAHAN & \\
\hline 2009 & $920,801,000$ & $389,011,000$ & $531,790,000$ & - & 0.00 \\
\hline 2010 & $917,699,000$ & $418,397,000$ & $499,302,000$ & TURUN & -6.11 \\
\hline 2011 & $1,150,989,000$ & $598,290,000$ & $552,699,000$ & NAIK & 10.69 \\
\hline 2012 & $1,262,551,000$ & $524,443,000$ & $738,108,000$ & NAIK & 33.55 \\
\hline 2013 & $1,198,904,000$ & $540,105,000$ & $658,799,000$ & TURUN & -10.74 \\
\hline 2014 & $1,067,583,000$ & $561,851,000$ & $505,732,000$ & TURUN & -23.23 \\
\hline 2015 & $829,331,000$ & $579,075,000$ & $250,256,000$ & TURUN & -50.52 \\
\hline 2016 & $598,774,000$ & $429,383,000$ & $169,391,000$ & TURUN & -32.31 \\
\hline
\end{tabular}

Jumlah Aktiva lancar cenderung mengalami penurunan tiap tahunnya sedangkan jumlah hutang lancarnya cenderung mengalami kenaikan, kondisi ini logis karena aktiva lancar khususnya kas digunakan untuk segera melunasi hutang lancar yang telah jatuh tempo dan tidak diimbangi dengan penurunan hutang lancar sehingga menyebabkan modal kerja mengalami penurunan.

Dari keadaan di atas dapat dikatakan bahwa modal kerja yang baik adalah ketika aktiva lancar naik maka diharapkan hutang lancar mengalami penurunan atau kenaikan hutang lancar harus diimbangi pula dengan kenaikan aktiva lancar, sedangkan penurunan aktiva lancar harus diimbangi pula dengan penurunan hutang lancar.

\section{Perputaran Modal Kerja}

Perputaran modal kerja merupakan bagian dari rasio aktivitas. Rasio perputaran modal kerja digunakan untuk mengukur keefektifan modal kerja (aset lancar) yang dimiliki perusahaan dalam menghasilkan penjualan. Rasio ini dihitung sebagai hasil bagi antara besarnya penjualan (tunai maupun kredit) dengan rata-rata asset/aktiva lancar. Berikut disajikan data aktiva lancar, rata-rata aktiva lancar, penjualan dan perputaran modal kerja yang diambil dari laporan keuangan PT. Pabrik Kertas Tjiwi Kimia Tbk dari tahun 2009-2016: 
Tabel 5. Perputaran Modal kerja PT. Pabrik Kertas Tjiwi Kimia Tbk tahun 2009 s/d tahun 2016 (dalam dolar AS)

\begin{tabular}{|c|c|c|c|c|}
\hline \multirow[t]{2}{*}{ Thn } & AKTIVA & RATA-RATA & PENJUALAN & PERPUTARAN \\
\hline & LANCAR & $\begin{array}{l}\text { AKTIVA } \\
\text { LANCAR } \\
\text { (a) }\end{array}$ & (b) & $\begin{array}{c}\text { MODAL } \\
\text { KERJA (\%) } \\
\text { (b/a) }\end{array}$ \\
\hline 2009 & $920,801,000$ & $920,801,000$ & $1,174,106,000$ & 127.51 \\
\hline 2010 & $917,699,000$ & $919,250,000$ & $1,338,766,000$ & 145.64 \\
\hline 2011 & $1,150,989,000$ & $1,034,344,000$ & $1,378,740,000$ & 133.30 \\
\hline 2012 & $1,262,551,000$ & $1,206,770,000$ & $1,321,641,000$ & 109.52 \\
\hline 2013 & $1,198,904,000$ & $1,230,727,500$ & $1,222,356,000$ & 99.32 \\
\hline 2014 & $1,067,583,000$ & $1,133,243,500$ & $1,194,755,000$ & 105.43 \\
\hline 2015 & $829,331,000$ & $948,457,000$ & $1,062,531,000$ & 112.03 \\
\hline 2016 & $598,774,000$ & $714,052,500$ & $996,902,000$ & 139.61 \\
\hline
\end{tabular}

Dari data tabel diatas terlihat rata-rata aktiva lancar PT. Pabrik Kertas Tjiwi Kimia Tbk. tertinggi pada tahun 2013 yaitu sebesar $\$ 1,230,727,500$ dan data penjualan tertinggi terjadi pada tahun 2011 yaitu sebesar $\$ 1,378,740,000$. Sedangkan rata-rata aktiva lancar terendah dan data penjualan terendah terjadi pada tahun 2016 yaitu sebesar $\$ 714,052,500$ dan $\$ 996,902,000$. Pada awal tahun 2010 dan 3 tahun terakhir rata-rata aktiva lancar mengalami penurunan. Penurunan aktiva lancar tertinggi terjadi pada tahun 2016 yaitu sebesar 24,71\%. Sedangkan kenaikan aktiva lancar tertinggi terjadi pada tahun 2012 yaitu sebesar $16,67 \%$.

Tidak berbeda dengan kondisi aktiva lancar, kondisi penjualan per tahun juga mengalami penurunan. Diawali dengan kenaikan pada 2 tahun pertama, kemudian untuk tahun-tahun selanjutnya mengalami penurunan. Kenaikan penjualan tertinggi terjadi pada tahun 2010 yaitu sebesar 14,02\%, sedangkan penurunan penjualan terendah terjadi pada tahun 2015 yaitu sebesar $11,07 \%$.

Pada table 5 memperlihatkan bahwa kenaikan dan penurunan penjualan juga diikuti dengan kenaikan dan penurunan rata-rata aktiva lancar. Kondisi seperti ini merupakan hal yang wajar karena hasil dari penjualan tersebut akan menjadi kas dan piutang dalam perusahaan. Namun bisa jadi kondisi seperti ini tidak efektif, karena jika dihitung dalam rasio perputaran modal kerja akan menghasilkan tingkat perputaran modal kerja yang rendah. Kondisi ratarata aktiva lancar yang tinggi berarti terdapat komponen modal kerja seperti kas, piutang dan persediaan mengendap atau kurang dimanfaatkan dengan baik.

Keefektifan modal kerja adalah ketika penjualan tingg namun dengan rata-rata aktiva lancar yang rendah, dengan begitu tingkat perputaran modal kerja yang dihasilkan akan tinggi. Tingkat perputaran kerja yang tinggi berarti waktu yang digunakan oleh komponen modal kerja (kas, piutang dan persediaan) untuk terbentuk kembali menjadi komponen modal kerja semakin cepat. Dengan begitu akan mempengaruhi pada jumlah produksi barang yang akan dijual, dengan penjualan yang tinggi maka akan menyebabkan keuntungan yang tinggi.

Pada tabel 5 perputaran modal kerja PT. Pabrik Kertas Tjiwi Kimia Tbk. dari tahun 2009 sampai dengan tahun 2016 mengalami 4 kali kenaikan dan 3 kali penurunan. Jumlah perputaran tertinggi adalah pada tahun 2010 yaitu sebesar 1,46 kali dan perputaran terendah adalah pada tahun 2013 yaitu sebesar 0,99 kali.

\section{Net Profit Margin (NPM)}

Marjin laba bersih merupakan rasio yang digunakan untuk mengukur besarnya persentase laba bersih atas penjualan bersih.Rasio ini dihitung dengan membagi laba bersih terhadap penjualan bersih.Laba bersih sendiri dihitung sebagai hasil pengurangan antara laba sebelum pajak penghasilan dengan beban pajak penghasilan.Yang dimaksud dengan laba sebelum pajak penghasilan di sini adalah laba operasional ditambah pendapatan dan keuntungan lain-lain, lalu dikurangi dengan beban dan kerugian lain-lain.Laba operasional sendiri didapat dari penjualan bersih dikurangi harga pokok penjualan dan dikurangi dengan beban usaha.

Berikut disajikan data laba operasional, penghasilan/beban lain-lain dan pajak pada tabel net income PT. Pabrik kertas Tjiwi Kimia Tbk. tahun 2009-2016:

Tabel 6. Net Income PT. Pabrik Kertas Tjiwi Kimia Tbk. Tahun 2009 s/d Tahun 2016 (dalam dolar AS)

\begin{tabular}{ccccc}
\hline Thn & LABA & PENGHASILAN/ & PAJAK & NET \\
\hline & $\begin{array}{c}\text { OPERASI- } \\
\text { ONAL }\end{array}$ & BEBAN & INCOME \\
\hline \multicolumn{5}{c}{ LAIN-LAIN } \\
\hline $\mathbf{2 0 0 9}$ & 119.831 .000 & $(47.423 .000)$ & $(40.754 .000)$ & 31.654 .000 \\
\hline $\mathbf{2 0 1 0}$ & 79.022 .000 & $(16.965 .000)$ & $(15.485 .000)$ & 46.572 .000 \\
\hline $\mathbf{2 0 1 1}$ & 105.397 .000 & $(14.906 .000)$ & $(20.079 .000)$ & 70.412 .000 \\
\hline $\mathbf{2 0 1 2}$ & 85.910 .000 & $(44.283 .000)$ & $(6.810 .000)$ & 34.817 .000 \\
\hline $\mathbf{2 0 1 3}$ & 31.199 .000 & $(16.374 .000)$ & 12.185 .000 & 27.010 .000 \\
\hline $\mathbf{2 0 1 4}$ & 21.922 .000 & $(10.840 .000)$ & 9.392 .000 & 20.474 .000 \\
\hline $\mathbf{2 0 1 5}$ & 13.026 .000 & $(24.685 .000)$ & 13.111 .000 & 1.452 .000 \\
\hline $\mathbf{2 0 1 6}$ & 10.938 .000 & $(10.056 .000)$ & 6.771 .000 & 7.653 .000 \\
\hline & $\begin{array}{l}\text { Sumber : Laporan } \\
2016\end{array}$ & & & \\
\hline
\end{tabular}

Popon Rabia Adawia ${ }^{1}$, Ayu Azizah ${ }^{2}$ Abdul Rokhim ${ }^{3}$ 
Berdasarkan tabel 6, laba bersih/net income perusahaan mengalami penurunan setelah dua kali mengalami kenaikan yaitu pada tahun 2010 dan 2011 . Laba bersih yang kecil bisa disebabkan karena jumlah beban dan pajak yang terlalu tinggi. Jika laba operasional lebih besar dibandingkan dengan beban dan pajak, maka kondisi ini perusahaan dalam keadaan untung. Jika laba operasional lebih kecil dibandingkan dengan beban dan pajak, maka kondisi ini perusahaan dalam keadaan rugi.

Untuk menghitung besarnya rasio Net Profit Margin dengan membandingkan laba bersih (net income) dengan data penjualan. Berikut disajikan Net Profit Margin yang diambil dari laporan keuangan PT. Pabrik kertas Tjiwi Kimia Tbk. tahun 2009-2010:

Tabel 7. Net Profit Margin PT. Pabrik Kertas Tjiwi Kimia Tbk.tahun 2009 s/d tahun 2016 (dalam dolar AS)

\begin{tabular}{|c|c|c|c|}
\hline \multirow[t]{2}{*}{ THN } & PENJUALAN & $\begin{array}{c}\text { NET } \\
\text { INCOME }\end{array}$ & $\begin{array}{c}\text { NET PROFIT } \\
\text { MARGIN } \\
(\%)\end{array}$ \\
\hline & (b) & (c) & $(\mathrm{c} / \mathrm{b})$ \\
\hline 2009 & $1,174,106,000$ & $31,654,000$ & 2.70 \\
\hline 2010 & $1,338,766,000$ & $46,572,000$ & 3.48 \\
\hline 2011 & $1,378,740,000$ & $70,412,000$ & 5.11 \\
\hline 2012 & $1,321,641,000$ & $34,817,000$ & 2.63 \\
\hline 2013 & $1,222,356,000$ & $27,010,000$ & 2.21 \\
\hline 2014 & $1,194,755,000$ & $20,474,000$ & 1.71 \\
\hline 2015 & $1,062,531,000$ & $1,452,000$ & 0.14 \\
\hline 2016 & $996,902,000$ & $7,653,000$ & 0.77 \\
\hline
\end{tabular}

Dari tabel 7 terlihat bahwa Net Profit Margin untuk 2 tahun pertama (2010 dan 2011) mengalami kenaikan dari tahun sebelumya yaitu sebesar 3,48 dan 5,11. Tahun 2012 sampai dengan tahun 2015 mengalami penurunan dan kemudian naik kembali pada tahun 2016. Persentase Net Profit Margin tertinggi terjadi pada tahun 2011 yaitu sebesar $5.11 \%$ dan persentase Net Profit Margin terendah terjadi pada tahun 2015 yaitu sebesar 0,14\%. Berkurangnya Net Profit Margin disebabkan karena bertambahnya beban dan pajak, sehingga mempengaruhi laba bersih atau Net income.

\section{Perbandingan antara Perubahan Modal kerja, Perputaran Modal kerja dan Net Profit Margin (NPM).}

Setelah menghitung jumlah persentase perubahan modal kerja, perputaran modal kerja dan Net Profit Margin PT. Pabrik kertas Tjiwi Kimia Tbk. dari tahun 2010 sampai dengan 2016 untuk mempermudah pengujian hipotesis maka hasil dari ketiga variabel tersebut dapat dilihat perbandingannya pada tabel berikut ini:

Tabel 8. Perubahan Modal Kerja, Perputaran Modal Kerja dan Net Profit Margin PT. Pabrik Kertas Tjiwi Kimia Tbk. Tahun 2006 s/d 2016

\begin{tabular}{lccc}
\hline \multirow{2}{*}{ THN } & PERUBAHAN & PERPUTARAN & NET PROFIT \\
\cline { 2 - 4 } & MODAL KERJA & MODAL KERJA & MARGIN \\
\cline { 2 - 4 } & $(\%)$ & $(\%)$ & $(\%)$ \\
\hline 2010 & -6.11 & 145.64 & 3.48 \\
\hline 2011 & 10.69 & 133.30 & 5.11 \\
\hline 2012 & 33.55 & 109.52 & 2.63 \\
\hline 2013 & -10.74 & 99.32 & 2.21 \\
\hline 2014 & -23.23 & 105.43 & 1.71 \\
\hline 2015 & -50.52 & 112.03 & 0.14 \\
\hline 2016 & -32.31 & 139.61 & 0.77 \\
\hline $\begin{array}{l}\text { Sumber }: \text { Laporan Keuangan Neraca PT Tjiwi Kimia } \\
\text { Penulis. }\end{array}$ & & & \\
\hline
\end{tabular}

\section{Pengujian Hipotesis Penelitian}

Dari analisis perubahan modal kerja, perputaran modal kerja dan Net Profit Margin PT. Pabrik Kertas Tjiwi Kimia Tbk. yang telah dijelaskan sebelumnya, selanjutnya adalah menentukan variabel perubahan modal kerja sebagai variabel bebas pertama (X1), perputaran modal kerja sebagai variabel bebas kedua (X2), dan Net Profit Margin sebagai variabel terikat (Y).

Langkah berikutnya adalah menguji kebenaran hipotesis yang telah dirumuskan sebelumnya dengan menggunakan uji statistik. Untuk mempermudah pengujian hipotesis digunakan perhitungan antar variabel yang bisa di lihat pada tabel di bawah ini:

Tabel 9 Tabel Penolong Perhitungan Analisis Regresi dan Korelasi PT. Pabrik Kertas Tjiwi Kimia Tbk.

\begin{tabular}{cccccc}
\hline No. & $\mathbf{X}_{\mathbf{1}}$ & $\mathbf{X}_{\mathbf{2}}$ & $\mathbf{Y}$ & $\mathbf{X}_{\mathbf{1}}{ }^{2}$ & $\mathbf{X}^{2}$ \\
\hline 1 & -6.11 & 145.64 & 3.48 & 37.32 & 21210.07 \\
\hline 2 & 10.69 & 133.30 & 5.11 & 114.37 & 17767.84 \\
\hline 3 & 33.55 & 109.52 & 2.63 & 1125.34 & 11994.39 \\
\hline 4 & -10.74 & 99.32 & 2.21 & 115.45 & 9864.42 \\
\hline 5 & -23.23 & 105.43 & 1.71 & 539.83 & 11115.05 \\
\hline 6 & -50.52 & 112.03 & 0.14 & 2551.87 & 12550.12 \\
\hline 7 & -32.31 & 139.61 & 0.77 & 1044.12 & 19491.47 \\
\hline$\sum$ & $\mathbf{- 7 8 . 6 8}$ & $\mathbf{8 4 4 . 8 4}$ & $\mathbf{1 6 . 0 5}$ & $\mathbf{5 5 2 8 . 3 1}$ & $\mathbf{1 0 3 9 9 3 . 3 6}$ \\
\hline
\end{tabular}


Analisis Pengaruh Perubahan dan Perputaran Modal Kerja Terhadap Net Profit Margin (NPM) pada PT. Pabrik Kertas Tjiwi Kimia Tbk.

\begin{tabular}{cccc}
\hline $\mathbf{Y}^{\mathbf{2}}$ & $\mathbf{X}_{\mathbf{1} . \mathbf{Y}}$ & $\mathbf{X}_{\mathbf{2} . \mathbf{Y}}$ & $\mathbf{X}_{\mathbf{1}} \cdot \mathbf{X}_{\mathbf{2}}$ \\
\hline 12.10 & -21.25 & 506.63 & -889.72 \\
\hline 26.08 & 54.62 & 680.74 & 1425.51 \\
\hline 6.94 & 88.37 & 288.51 & 3673.93 \\
\hline 4.88 & -23.74 & 219.46 & -1067.18 \\
\hline 2.94 & -39.82 & 180.67 & -2449.54 \\
\hline 0.02 & -6.90 & 15.31 & -5659.18 \\
\hline 0.59 & -24.81 & 107.18 & -4511.27 \\
\hline $\mathbf{5 3 . 5 5}$ & $\mathbf{2 6 . 4 7}$ & $\mathbf{1 9 9 8 . 5 0}$ & $\mathbf{- 9 4 7 7 . 4 4}$ \\
\hline
\end{tabular}

Sumber : Penulis

\section{Uji Statistik}

a. Analisis Regresi Linier Berganda

Regresi linier berganda merupakan prosedur yang berfungsi untuk melihat hubungan linier antara lebih dari satu variabel yang diidentifikasi sebagai variabel independen atau bebas dengan satu variabel lain yang diidentifikasi sebagai variabel dependen atau tergantung. Linieritas dalam hubungan ini menyiratkan fluktuasi nilai variabel bebas diasumsikan mempengaruhi variabel terikat.

Dengan melihat tabel penolong perhitungan analisis regresi dan korelasi (tabel 3.7) maka langkah selanjutnya sebagai berikut:

$\mathbf{Y}=\mathbf{a}+\mathbf{b}_{1} \mathbf{X}_{1}+\mathbf{b}_{2} \mathbf{X}_{2}$

Dari persamaan di atas kita harus mencari nilai b1, b2 dan a dengan menggunakan rumus sebagai berikut:

$$
\begin{gathered}
\mathbf{b}_{1}=\frac{\left(\mathrm{SS}_{2}\right)\left(\mathrm{SCP}_{1 \mathrm{y}}\right)-\left(\mathrm{SCP}_{12}\right)\left(\mathrm{SCP}_{2 \mathrm{y}}\right)}{\left(\mathrm{SS}_{1}\right)\left(\mathrm{SS}_{2}\right)-\left(\mathrm{SCP}_{12}\right)^{2}} \\
\mathbf{b}_{\mathbf{2}}=\frac{\left(\mathrm{SS}_{1}\right)\left(\mathrm{SCP}_{2 \mathrm{y}}\right)-\left(\mathrm{SCP}_{12}\right)\left(\mathrm{SCP}_{1 \mathrm{y}}\right)}{\left(\mathrm{SS}_{1}\right)\left(\mathrm{SS}_{2}\right)-\left(\mathrm{SCP}_{12}\right)^{2}} \\
\mathbf{a}=\mathbf{Y}-\mathbf{b}_{\mathbf{1}} \mathbf{X}_{\mathbf{1}}-\mathbf{b}_{2} \mathbf{X}_{\mathbf{2}}=\left(\frac{\sum \mathrm{Y}}{\mathrm{n}}\right)-\mathbf{b} \mathbf{1}\left(\frac{\sum \mathrm{X} 1}{\mathrm{n}}\right)-\mathbf{b} \mathbf{2}\left(\frac{\sum \mathrm{X} 2}{\mathrm{n}}\right)
\end{gathered}
$$

Untuk mencari nilai-nilai di atas, maka kita harus mencari terlebih dahulu nilai $\mathrm{SS}_{1}, \mathrm{SS}_{\mathrm{y}}$, dan $\mathrm{SS}_{2}$ dengan rumus sebagai berikut:

$$
\begin{aligned}
\mathrm{SS}_{1}=\sum \mathrm{x}_{1}{ }^{2} & =\sum \mathrm{X}_{1}{ }^{2}-\frac{\left(\sum \mathrm{X}_{1}\right)^{2}}{\mathrm{n}} \\
& =4644.02 \\
\mathrm{SS} 2=\sum \mathrm{x} 22 & =\sum \mathrm{X} 22-\frac{\left(\sum \mathrm{X} 2\right) 2}{\mathrm{n}}
\end{aligned}
$$

$$
=2028.74
$$

$$
\begin{aligned}
\mathrm{SS}_{\mathrm{y}}=\sum \mathrm{y}^{2} & =\sum \mathrm{Y}^{2}-\frac{\left(\sum \mathrm{Y}\right)^{2}}{\mathrm{n}} \\
& =16.76
\end{aligned}
$$

Mencari nilai $\mathrm{SCP}_{12}$ dengan rumus sebagai berikut:

$$
\begin{aligned}
\mathrm{SCP}_{12}=\sum \mathrm{x}_{1} \mathrm{X}_{2} & =\sum \mathrm{X}_{1} \mathrm{X}_{2}-\frac{\left(\sum \mathrm{X}_{1}\right)\left(\sum \mathrm{X}_{2}\right)}{\mathrm{n}} \\
& =18.17
\end{aligned}
$$

Mencari nilai $\mathrm{SCP}_{1 \mathrm{y}}$ dengan rumus sebagai berikut:

$$
\begin{aligned}
& \begin{array}{c}
\mathrm{SCP}_{1 \mathrm{y}}= \\
\sum \mathrm{x}_{1} \mathrm{y}
\end{array}=\sum \mathrm{X}_{1} \mathrm{Y}-\frac{\left(\sum \mathrm{X}_{1}\right)\left(\sum \mathrm{Y}\right.}{2} \\
& =206.84
\end{aligned}
$$

Mencari nilai $\mathrm{SCP}_{2 \mathrm{y}}$ dengan rumus sebagai berikut:

$$
\begin{aligned}
\mathrm{SCP}_{2 \mathrm{y}}=\sum \mathrm{x}_{2} \mathrm{y} & =\sum \mathrm{X}_{2} \mathrm{Y}-\frac{\left(\sum \mathrm{X}_{2}\right)\left(\sum \mathrm{Y}\right.}{2} \\
& =61.68
\end{aligned}
$$

Setelah ditemukan nilai-nilai di atas $\left(\mathrm{SS}_{1} . \mathrm{SS}_{2}\right.$, SSy, $\mathrm{SCP}_{12}, \mathrm{SCP}_{1} \mathrm{y}$ dan $\mathrm{SCP}_{2} \mathrm{y}$ ) kemudian di masukkan ke dalam rumus $\mathbf{b}_{1}, \mathbf{b}_{2}$ dan a. Hasil perhitungan diperoleh nilai $b_{1}=0.04, b_{2}=0.03$ dan $\mathrm{a}=-0.83$.

Dari hasil analisis regresi linier berganda di atas dapat diketahui bahwa nilai konstanta (a) sebesar -0,83 sedangkan nilai koefisien regresi variabel bebas pertama $\left(b_{1}\right)$ sebesar 0,04 dan koefisien regresi bebas kedua $\left(b_{2}\right)$ sebesar 0,03 maka didapat persamaan regresi linier yaitu:

$$
Y=-0,83+0,04 X_{1}+\mathbf{0 , 0 3 X _ { 2 }}
$$

Adapun maksud dari persamaan tersebut adalah:

1) $\mathbf{a}=-0,83$

Net Profit Margin yang terbentuk adalah sebesar -0,83 apabila perubahan modal kerja (X1) dan perputaran modal kerja (X2) bernilai 0 .

2) $\mathbf{b}_{1}=0,04$

Setiap kenaikan perubahan modal kerja sebesar 1 satuan, maka Net Profit Margin akan naik sebesar 0,04

3) $\mathbf{b}_{2}=0,03$

Setiap kenaikan perputaran modal kerja sebesar 1 satuan, maka Net Profit Margin akan naik sebesar 0,03 . 
b. Koefisien Korelasi Parsial

Koefisien korelasi parsial digunakan untuk mengetahui hubungan antar variabel secara sendiri-sendiri/parsial. Sebelum menghitungnya, perlu dilakukan perhitungan koefisien korelasi antar masing-masing variabel berikut ini:

1) Koefisien korelasi antara $X_{1}$ dan $Y$

$$
r_{1 y}=\frac{\mathrm{SCP}_{1 \mathrm{y}}}{\sqrt{ }\left(\mathrm{SS}_{1}\right)\left(\mathrm{SS}_{\mathrm{y}}\right)}=0.74
$$

2) Koefisien korelasi antara $X_{2}$ dan $Y$

$$
r_{2 y}=\frac{\mathrm{SCP}_{2 \mathrm{y}}}{\sqrt{ }\left(\mathrm{SS}_{2}\right)\left(\mathrm{SS}_{\mathrm{y}}\right)}=0.33
$$

3) Koefisien korelasi antara $X_{1}$ dan $X_{2}$

$$
r_{12}=\frac{\mathrm{SCP}_{12}}{\sqrt{ }\left(\mathrm{SS}_{1}\right)\left(\mathrm{SS}_{2}\right)}=0.01
$$

Hubungan antar variabel secara sendirisendiri/parsial adalah:

1) Koefisien korelasi variabel $Y$ dan $X_{1}\left(X_{2}\right.$ dianggap konstan):

$$
r_{1 y .2}=\frac{r_{1 y}-r_{2 y} r_{12}}{\sqrt{ }\left(1-r_{2 y}^{2}\right)\left(1-r_{12}^{2}\right)}=0.78
$$

2) Koefisien korelasi variabel $Y$ dan $X_{2}\left(X_{1}\right.$ dianggap konstan):

$$
r_{2 y .1}=\frac{r_{2 y}-r_{1 y} r_{12}}{\sqrt{ }\left(1-r_{1 y}{ }_{1 y}\right)\left(1-r_{12}^{2}\right)}=0.49
$$

3) Menghitung koefisien korelasi variabel $X_{1}$ dan $\mathrm{X}_{2}$ (Y dianggap konstan):

$$
r_{12 . y}=\frac{r_{12}-r_{1 y} r_{2 y}}{\sqrt{ }\left(1-r^{2}{ }_{1 y}\right)\left(1-r^{2}{ }_{2 y}\right)}=-0.83
$$

Dengan melihat pedoman tabel 2.2 tingkat interval koefisien korelasi, hasil koefisien korelasi parsial antara perubahan modal kerja dan Net Profit Margin diperoleh nilai sebesar 0,78, yang berarti perubahan modal kerja dan Net Profit Margin pada PT. Pabrik Kertas Tjiwi Kimia Tbk. memiliki tingkat hubungan yang positif dan kuat, sedangkan perputaran modal kerja dan Net Profit Margin diperoleh nilai sebesar 0,49, yang berarti perputaran modal kerja dan Net Profit Margin memiliki tingkat hubungan yang positif dan cukup kuat. Dan untuk hubungan antara perubahan modal kerja dan perputaran kerja itu sendiri diperoleh hasil $-0,38$ yang berarti negatif dan rendah.

c. Koefisien Korelasi Simultan

Koefisien korelasi simultan digunakan untuk mengetahui berapa besar pengaruh hubungan variabel independen secara bersamasama/simultan terhadap variabel dependen. Besarnya hubungan variabel perubahan modal kerja dan perputaran modal kerja terhadap Net Profit Margin adalah:

$$
\begin{aligned}
& \mathbf{R}_{\mathbf{y 1 2}}=\sqrt{\frac{\mathrm{r}^{2}{ }_{1 \mathrm{y}}+\mathrm{r}^{2}{ }_{2 \mathrm{y}}-2 \mathrm{r}_{1 \mathrm{y}} \mathrm{r}_{2 \mathrm{y}} \mathrm{r}_{12}}{1-\mathrm{r}_{12}{ }_{12}}} \\
& \mathbf{R}_{\mathbf{y 1 2}}=\sqrt{\frac{0.74^{2}+0.33^{2}-2 \mathrm{x} 0.74 \times 0.33 \times 0.01}{1-0.01^{2}}} \\
& \mathbf{R}_{\mathbf{y} 12}=0.81
\end{aligned}
$$

Dari hasil perhitungan koefisien korelasi secara simultan/bersama-sama diperoleh nilai sebesar 0,81 . Dengan melihat tabel pedoman interval koefisien korelasi maka nilai tersebut digolongkan dalam tingkat hubungan yang positif dan sangat kuat, ini berarti hubungan antara perubahan modal kerja dan perputaran modal kerja terhadap Net Profit Margin pada PT. Pabrik Kertas Tjiwi Kimia Tbk. Adalah positif dan sangat kuat.

\section{d. Koefisien Determinasi}

Koefisisen determinasi digunakan untuk menyatakan besarnya proporsi variasi dari variabel dependen (tergantung) yang dapat dijelaskan oleh proporsi variabel independen (bebas) atau prediktor. Besarnya koefisisen determinasi variabel perubahan modal kerja dan perputaran modal kerja terhadap Net Profit Margin adalah:

$$
\begin{aligned}
\mathbf{K D B} & =\mathbf{R}_{\mathbf{y} 12}^{2} \times 100 \% \\
& =0.81^{2} \times 100 \% \\
& =65,61 \%
\end{aligned}
$$

Hasil perhitungan Koefisien Determinasi Berganda (KDB) menunjukkan nilai sebesar 65,61\%, ini berarti variasi tingkat Net Profit Margin (NPM) pada PT. Pabrik Kertas Tjiwi Kimia Tbk. Sebesar 65,61\% dipengaruhi oleh perubahan modal kerja dan perputaran modal kerja dan sisanya sebesar $34,39 \%$ dipengaruhi 
oleh faktor lain yang tidak diteliti dalam penelitian ini seperti volume penjualan, beban, dan lain-lain.

\section{Uji t (Pengujian Kelayakan Hipotesis Parsial)}

Pengujian hipotesis dengan menggunakan uji $\mathrm{t}(\mathrm{t}$ test $)$ bertujuan untuk mengetahui apakah variabel independen/bebas dalam model regresi berpengaruh terhadap variabel dependen/terikat. Hipotesis operasional dalam penelitian ini adalah:

$\mathrm{HO}_{1}$ : Tidak terdapat pengaruh positif dan signifikan perubahan modal kerja terhadap Net Profit Margin (NPM).

$\mathrm{H} 1_{1}$ : Terdapat pengaruh positif dan signifikan perubahan modal kerja terhadap Net Profit Margin (NPM).

$\mathrm{HO}_{2}$ : Tidak terdapat pengaruh positif dan signifikan perputaran modal kerja terhadap Net Profit Margin (NPM).

$\mathrm{H}_{2}$ : Terdapat pengaruh positif dan signifikan perputaran modal kerja terhadap Net Profit Marjin (NPM).

Uji ini dilakukan dengan membandingkan hasil nilai $\mathrm{t}$ tabel dengan $\mathrm{t}$ hitung dengan kriteria sebagai berikut:

Jika t hitung $\left(\mathrm{t}_{0}\right)>\mathrm{t}$ tabel maka $\mathrm{H} 0$ ditolak dan $\mathrm{H} 1$ diterima

Jika t hitung $\left(\mathrm{t}_{0}\right)<\mathrm{t}$ tabel maka $\mathrm{H} 0$ diterima dan $\mathrm{H} 1$ ditolak.

Langkah pertama adalah menghitung nilai t table dengan ketentuan sebagai berikut:

Nilai $\alpha=5 \%$ atau 0,05 harus dibagi dua sehingga menjadi 0,025 .

Degree of Freedom (DF) $=\mathrm{n}-\mathrm{k}$ (jumlah data dikurangi jumlah variabel).

$\mathrm{t}$ tabel $=\mathrm{t}_{\alpha / 2, \mathrm{DF}}=\mathrm{n}-\mathrm{k}=\mathrm{t}_{0,025, \mathrm{DF}=7-3=4}=2,776$

Nilai t tabel sebesar 2,776 didapat dari melihat pedoman $t$ tabel statistik.

Langkah kedua menghitung nilai t hitung $\left(\mathrm{t}_{0}\right)$ dengan rumus:

$$
\text { thitung }\left(t_{0}\right)=\frac{b_{k}}{s b_{k}}
$$

a. Rumus t hitung variabel bebas perubahan modal kerja (X1)

$$
\text { thitung }\left(\mathrm{t}_{0.1}\right)=\frac{\mathrm{b}_{1}}{\mathrm{Sb}_{1}}
$$

b. Rumus $\mathrm{t}$ hitung variabel bebas perputaran modal kerja (X2)

$$
\mathrm{t} \text { hitung }\left(\mathrm{t}_{0.2}\right)=\frac{\mathrm{b}_{2}}{\mathrm{Sb}_{2}}
$$

Dengan menggunakan rumus:

$$
\begin{aligned}
& \mathrm{Sb}_{1}=\quad \mathrm{Sy}_{1.2}=\quad \sqrt{\frac{\mathrm{MS}_{\mathrm{res}}}{\mathrm{SS}_{1}\left(1-\mathrm{r}_{12}{ }^{2}\right)}} \\
& \mathrm{Sb}_{2}=\quad \mathrm{Sy}_{2.1}=\quad \sqrt{\frac{\mathrm{MS}_{\mathrm{res}}}{\mathrm{SS}_{2}\left(1-\mathrm{r}_{12}{ }^{2}\right)}}
\end{aligned}
$$

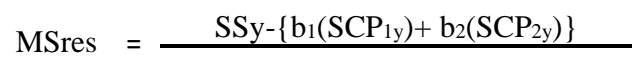

k-1

$$
\mathrm{r}_{12^{2}}=\frac{\left(\mathrm{SCP}_{12}\right)^{2}}{\left(\mathrm{SS}_{1}\right)\left(\mathrm{SS}_{2}\right)}
$$

Maka nilai $\mathrm{t}$ hitung ( $\left.\mathrm{t}_{0}\right)$ untuk masing-masing variabel adalah:

a. Rumus t hitung variabel bebas perubahan modal kerja (X1)

$$
\begin{aligned}
\mathrm{t}_{0.1} & =\frac{\mathrm{b}_{1}}{\mathrm{sb}_{1}} \\
& =\frac{0.04}{0.025} \\
& =1.612
\end{aligned}
$$

b. Rumus $\mathrm{t}$ hitung variabel bebas perputaran modal kerja (X2)

$$
\begin{aligned}
\mathrm{t}_{0.2} & =\frac{\mathrm{b}_{2}}{\mathrm{sb}_{2}} \\
& =\frac{0.03}{0.038} \\
& =0.799
\end{aligned}
$$

Setelah nilai t hitung untuk masing-masing variabel bebas diketahui kemudian membandingkannya dengan nilai t tabel untuk ditarik kesimpulannya. 
a. Untuk variabel bebas perubahan modal kerja (X1)

Nilai t hitung $\left(\mathrm{t}_{0.1}\right)$ didapat sebesar 1,612 dan nilai $\mathrm{t}$ tabel sebesar 2,776, ini menunjukkan bahwa nilai t hitung lebih kecil dibandingkan dengan nilai $\mathrm{t}$ tabel ( $\mathrm{t}$ hitung $<\mathrm{t}$ tabel) yang berarti $\mathrm{H} 0_{1}$ diterima dan $\mathrm{H} 1_{1}$ ditolak. Dengan demikian dapat disimpulkan bahwa perubahan modal kerja tidak memiliki pengaruh yang positif dan signifikan terhadap Net Profit Margin pada PT. Pabrik Kertas Tjiwi Kimia Tbk.

b. Untuk variabel bebas perputaran modal kerja (X2)

Nilai $\mathrm{t}$ hitung $\left(\mathrm{t}_{0.2}\right)$ didapat sebesar 0,799 dan nilai $\mathrm{t}$ tabel sebesar 2,776, ini menunjukkan bahwa nilai t hitung lebih kecil dibandingkan dengan nilai $\mathrm{t}$ tabel ( $\mathrm{t}$ hitung $<\mathrm{t}$ tabel) yang berarti $\mathrm{HO}_{2}$ diterima dan $\mathrm{H}_{2}$ ditolak. Dengan demikian dapat disimpulkan bahwa perputaran modal kerja tidak memiliki pengaruh yang positif dan signifikan terhadap Net Profit Marginpada PT. Pabrik Kertas Tjiwi Kimia Tbk..

\section{KESIMPULAN}

Dengan melihat kriteria yang telah ditetapkan di atas maka kesimpulannya adalah:

Hasil korelasi parsial antara perubahan modal kerja dan Net Profit Margin diperoleh nilai sebesar 0,78, yang berarti perubahan modal kerja dan Net Profit Margin pada PT. Pabrik Kertas Tjiwi Kimia Tbk. memiliki tingkat hubungan yang positif dan kuat, namun berdasarkan uji t membuktikan bahwa nilai $\mathrm{t}$ hitung untuk variabel perubahan modal kerja $\left(\mathrm{t}_{0.1}\right)$ lebih kecil dari t tabel $\left(\mathrm{t}_{0.1} 1,612<2,776\right)$ ini berarti perubahan modal kerja tidak memiliki pengaruh yang positif dan signifikan terhadap Net Profit Margin (NPM) pada PT. Pabrik Kertas Tjiwi Kimia Tbk. Tahun 2010-2016.

Dengan hasil ini membuktikan bahwa pihak-pihak dalam perusahaan telah berupaya keras dalam mengelola keefektifan modal kerja, terutama kebijakan dalam hal pengelolaan aktiva lancar dan hutang lancar. Secara teoritis perubahan modal kerja yang meningkat akan meningkatkan jumlah produksi barang sehingga penjualan diharapkan meningkat. Dengan meningkatnya penjualan disertai biaya yang rendah, diharapkan akan meningkatkan laba bersih/net income yang nantinya akan berpengaruh terhadap kenaikan Net Profit Margin (NPM).

Hasil korelasi parsial antara perputaran modal kerja dan Net Profit Margin diperoleh nilai sebesar 0,49, yang berarti perputaran modal kerja dan Net Profit Margin memiliki tingkat hubungan yang positif dan cukup kuat, namun berdasarkan uji $t$ membuktikan bahwa nilai t hitung untuk variabel perputaran modal kerja $\left(\mathrm{t}_{0.2}\right)$ lebih kecil dari t tabel $\left(\mathrm{t}_{0.2} \quad 0,799<2,766\right)$ ini berarti perubahan modal kerja tidak memiliki pengaruh yang positif dan signifikan terhadap Net Profit Margin (NPM) pada PT. Pabrik Kertas Tjiwi Kimia Tbk. tahun 20102016.

Dengan hasil ini membuktikan bahwa pihak-pihak dalam perusahaan telah berupaya secara efektif dalam memutar modal kerja. Secara teoritis perputaran modal kerja yang efektif akan meningkatkan profitabilitas. Karena semakin tinggi perputaran modal kerja akan mempercepat kas yang tertanam menjadi kas kembali, jumlah piutang tak tertagih menjadi sedikit, dan mempercepat arus persediaan barang yang dijual.

Dengan begitu diharapkan akan meningkatkan laba bersih/net income yang nantinya akan berpengaruh terhadap kenaikan Net Profit Margin (NPM).

\section{REFERENSI}

Adawia, P. R., Azizah, A., \& Rokhim, A. (2019). Analisis Pengaruh Perubahan dan Perputaran Modal Kerja Terhadap Net Profit Margin (NPM) pada PT. Pabrik Kertas Tjiwi Kimia Tbk. Moneter, 6(1), 69-80.

Adawia, Popon Rabia, A. azizah dan R. Y. (2017). Analisis Pengaruh Modal Kerja terhadap Profitabilitas Pada PT. Mandom Tbk. STAR, XIV No.3.

Azizah, A. dan P. R. A. (2017). Analisis Structure Conduct Performance Pada PT. Telekomunikasi Indonesia. PERSPEKTIF, Vol.15 No.

Harjito, D. A. dan M. (2014). Manajemen Keuangan (Kedua). Yogjakarta: Ekonisia.

Hery. (2015). Laporan Analisa Keuangan. Yogjakarta: CAPS (Centre of Academic Publisihing Service).

Jonathan dan Hendra Nur Salim. (2017). Prosedurprosedur Popular Statistik untuk Analisa Data Riset Skripsi. Yogjakarta: Gaya Media.

Kasmir. (2013). Analisa Laporan Keuangan. Jakarta: PT. Raja Grafindo Perkasa.

Sugiyono. (2012). Metode Penelitian Bisnis. Bandung: Alfabeta. 
Analisis Pengaruh Perubahan dan Perputaran Modal Kerja Terhadap Net Profit Margin (NPM) pada PT. Pabrik Kertas Tjiwi Kimia Tbk.

\section{PROFIL PENULIS}

Popon Rabia Adawia, Penulis 1, memperoleh gelar Sarjana Ekonomi (SE) Jurusan Akuntansi, STIE YAI Jakarta dan gelar S2 dari program Pasca Sarjana Magister Manajemen Universitas Persada Indonesia YAI Jakarta. Saat ini menjadi Dosen Luar Biasa di UBSI Jakarta.

Ayu Azizah, Penulis 2, memperoleh gelar Sarjana Ekonomi (SE), Jurusan manajemen Universitas Sultan Ageng Tirtayasa, lulus 2010. Gelar S2
Magister Manajemen (MM) Universitas BSI Bandung. Saat ini menjadi Dosen Luar Biasa di UBSI Bandung.

Abdul Rokhim, Penulis 3, memperoleh gelar Sarjana Ekonomi (SE) Jurusan Akuntansi, STIE YPN, Karawang. 